
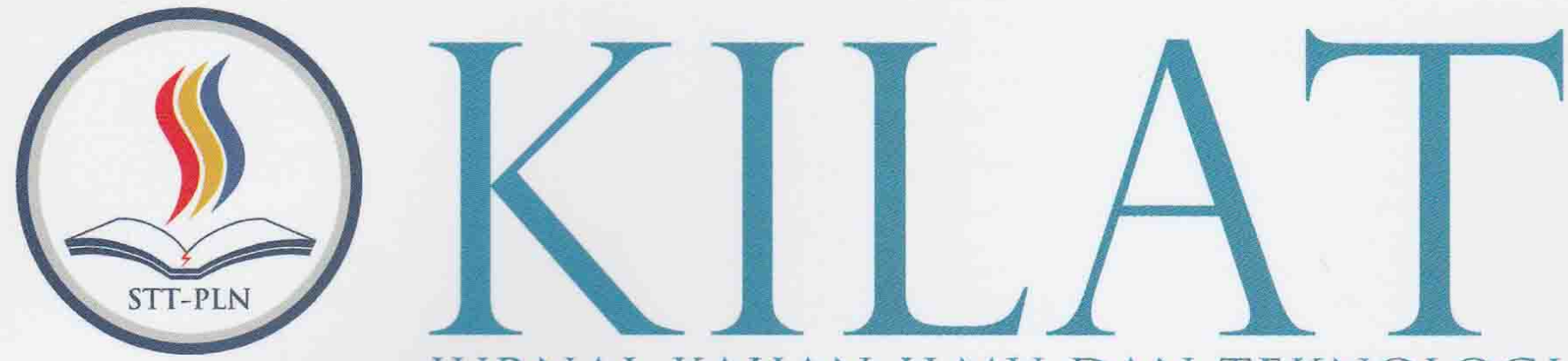

JURNAL KAJIAN ILMU DAN TEKNOLOGI

Endah Lestari: Irma Wirantina K: Ranti Hidayawanti

Faisal:

Muhammad Ridwan: Mardawati

Gita Puspa Artiani: Indah Handayasari

Kresna Ramanda; Irmawati Carolina

Ratna Mutu Manikam:

Farid Setiawan

Rayung Wulan

Roni Kartika Pramuyanti

Rr. Mekar Ageng Kinasti; Djoko Nugroho Notodisuryo

Satria;

Ayu Setiawati Agustini

Syam Gunawan: Pritasari Palupiningsih

Ali Ridho Gumelar: Anton: Ummu Radiyah

M. Yoga Distra Sudirman: Yessy Fitriani
ANALISA TAMAN ATAP DALAM UPAYA MENGURANGI LIMPASAN AIR HUJAN PADA BANGUNAN PERKOTAAN

OPTIMASI DIAGRAM LAYANAN PEMBELIAN DALAM MENDUKUNG MANAJEMEN HUBUNGAN PELANGGAN

OPTIMALISASI PENGOLAHAN SAMPAH ORGANIK DENGAN TEKNOLOGI BIODIGESTER SEBAGAI UPAYA KONSERVASI LINGKUNGAN

SELEKSI FITUR ALGORITMA NEURAL NETWORK MENGGUNAKAN PARTICLE SWARM OPTIMIZATION UNTUK MEMPREDIKSI KELAHIRAN PREMATUR

RANCANG BANGUN MEDIA BELAJAR FISIKA DASAR UNTUK MAHASISWA BERBASIS ANDROID

ANALISIS GLOBAL POSITIONING INFRASTRUKTUR DAN JARINGAN SOSIAL MEDIA DALAM BISNIS APLIKASI TRANSPORTASI DARAT ONLINE DI JAKARTA

PENGARUH INOVASI ANTENA PADA SIARAN TELEVISI MOBIL

PEMANFAATAN LIMBAH PEMBAKARAN BATUBARA (BOTTOM ASH) PADA PLTU SURALAYA SEBAGAI MEDIA TANAM DALAM UPAYA MENGURANGI PENCEMARAN LINGKUNGAN

PENERAPAN METODE GRAPHIC RATING SCALE (GRS) DALAM PENILAIAN KINERJA KARYAWAN

PEMBENTUKAN MODEL KLASIFIKASI DATA LAMA STUDI MAHASISWA STMIK INDONESIA MENGGUNAKAN DECISION TREE DENGAN ALGORITMA NBTREE

IMPLEMENTASI LOAD BALANCING DENGAN ALGORITMA EQUAL COST MULTI PATH (ECMP)

RANCANGAN SISTEM PENILAIAN HASIL KINERJA MULTI COMPANY DAN CROSS BUSINESS SECTOR 


\title{
PENGARUH INOVASI ANTENA PADA SIARAN TELEVISI MOBIL
}

\author{
Roni Kartika Pramuyanti \\ Fakultas Teknik, Program Studi Teknik Elektro \\ Universitas Semarang
}

\begin{abstract}
ABSTRAK
Optimalisasi siaran televisi mobil akan didapatkan dengan beberapa cara, salah satunya adalah dengan pengaturan dari antenna dari televisi mobil tersebut. Beberapa parameter disamping antenna perlu perhitungan yang cukup teliti dengan melihat juga posisi serta jarak dari pemancar. Penguat atau amplifier atau pada antena mobil biasa dikenal sebagai booster diperlukan dalam penguatan sinyal termasuk tegangan yang mempunyai masukan 12 Volt. Booster antena mobil yang digunakan disini adalah eksternal booster. Daya Pancar dan Terima Antena berbanding terbalik dengan panjang atau jarak. Dengan menggunakan antenna serta booster DXXN1508 penguatan booster adalah 40-46 kali. Jika secara perhitungan diambul penguatan $45 \mathrm{x}$, maka dengan tegangan masukan antenna $12 \mathrm{~V}$, maka akan didapat tegangan keluaran yang sangat besar.
\end{abstract}

Kata kunci : Antena, Booster, Amplifier, Internal, Eksternal, DXXN1508

\section{ABSTRACT}

The best or optimation of mobile television broadcast will be got some ways, one of this is the antenna's control of mobile's te;evision. The additionals require a fairly thorough calculation with look te position and the distance fron the transmitter. Amplifier of the antenna is called the booster. That is needed voltage enlarge, the input voltage is 12 volt. In this research use the eksternal booster. Transmit power and receive power od antenna inversely proportional distance. With use antenna and booster DXXN 1508 strengening booster is 40-46 $\mathrm{x}$. If in this calculate we use $45 \mathrm{x}$, input voltage $12 \mathrm{~V}$, the output voltage will be very lage.

Keywords: antenna, Booster, Amplifier, internal, Eksternal, DXXN1508

\section{PENDAHULUAN}

Televisi mobil mempunyai spesifikasi khusus sehingga dapat digunakan dalam kondisi bergerak atau move. Seperti halnya pada siaran radio yang digunakan pada kondisi bergerak pasti akan mempunyai banyak gangguan apalagi jika mengingat bahwa televisi mobil membawa sinyal video atau gambar tidak hanya siaran audio atau suara. Oleh karena itu dibutuhkan pilihan antara Televisi Analog atau digital, penggunaan booster serta antena.

Permasalah yang didapatkan dengan penggunaan Televisi mobil dalam kondisi bergerak cenderung tidak bersih atau banyak mengalami gangguan. Dari hal tersebut perumusan masalah dari penelitian ini adalah berusaha mendapatkan penerimaan video atau gambar serta suara pada pesawat televisi yang bersih dan jernih secara optimal. Dari sedikit permasalahan yang timbul diatas, diusahakan memasang antenna pada mobil dimana dapat menangkap siaran televisi UHF (Ultra High Frekuency, frekuensi yang sangat tinggi). Selain itu dilakukan pengaturan kedudukan antenna yang biasanya berada diluar, tetapi menempel body mobil.

Tujuan umum dari penelitian ini adalah dapat memperoleh atau menangkap siaran televisi yang paling baik pada perjalanan menggunakan mobil Ertiga.

\section{METODOLOGI PENELITIAN}

\subsection{Tahap Penelitian}

Untuk mencapai tujuan tersebut digunakan metodologi aplikasi langsung baik pemasangan, permasalahan maupun penyelesaian masalah.

1. Bahan dan Materi Penelitian

Bahan penelitian yang dipergunakan adalah :

a). Antena mobil UHF

b). TV mobil 7 inchi Avelino dt 888 tv

2. Meteri yang dipergunakan

Materi yang dipergunakan pada penelitian adalah :

a). Menampilkan acara TV yang berasal dari VCD dan DVD

b). Menampilkan acara TV yang berasal dari stasiun TV yang ada

c). Menganalisa siaran masing-masing stasiun TV.

3. Perancangan penelitian :

Menganalisa tampilan gambar maupun suara masing-masing siaran stasiun TV.

Menyesuaikan letak serta kedudukan antenna sehingga didapatkan tampilan yang optimal.

\subsection{Penelitian Lapangan}

Selain menyesuaiakan pemasangan TV mobil lengkap dengan antenna serta booster. dilakukan pula uji coba lapangan. Selama melakukan pengetesan atau pengecekan baik serta buruknya siaran televisi mobil Ertiga dilakukan perjalanan dari kota Yogyakarta hingga wilayah wonosari, solo 
maupun kota semarang. Selama melakukan perjalanan ini, TV mobil sengaja dihidupkan baik dengan siaran televisi/ TV local dan nasional maupun VCD atau DVD.

Blok diagram langkah-langkah penelitian :

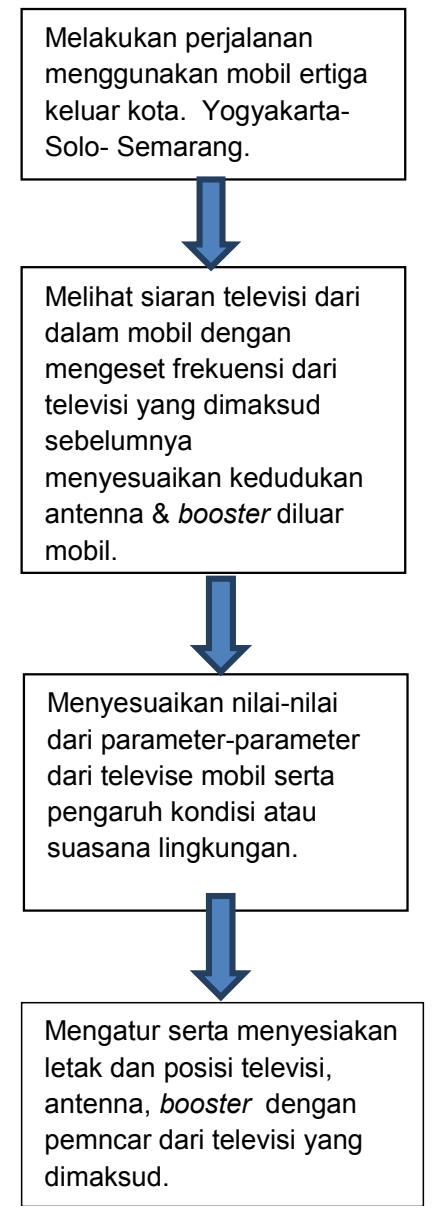

Gambar 1. Blok Langkah-langkah Yang dilakukan pd penelitian

\section{HASIL DAN PEMBAHASAN}

Penelitian ini memberikan 2 macam hasil yaitu hasil berupa data perhitungan dari parameter yang ada untuk dianalisa secara teori \& rumus, serta hasil penelitian yang berupa penerapan siaran televisi lokal mobil secara bagus, baik dan tidak mudah terkena pengaruh lingkungan.

\subsection{Antena}

Antena merupakan komponen elektronika yang biasa digunakan dalam telekomunikasi. Digunakannya antena adalah karena antena sangat berguna antuk pemancaran maupun penerimaan siaran baik audio maupun video. Antena adalah transformator/struktur transmisi antara gelombang terbimbing (saluran transmisi) dengan gelombang ruang bebas atau sebaliknya. Antena adalah salah satu elemen penting yang harus ada pada sebuah teleskop radio, TV, radar, dan semua alat komunikasi nirkabel lainnya.
Sebuah antena, $\mathrm{h}$ bagian vital dari suatu pemancar atau penerima yang berfungsi untuk menyalurkan sinyal radio ke udara

Fungsi antena adalah untuk mengubah sinyal listrik menjadi sinyal elektromagnetik, lalu meradiasikannya ke udara/ruang bebas). Sebaliknya, antena juga berfungsi menerima sinyal elektromagnetik ( penerima energy elektromagnetik dari ruang bebas) dan mengubahnya menjadi sinyal listrik. Ada antena yang melakukan kedua fungsi (peradiasi dan penerima) sekaligus.

Faktor utama yang menentukan seberapa bagusnya sebuah antena dalam menerima signal yaitu jarak dan arah antara antena itu dengan pemancar stasiun televisi (transmitter), dan juga kekuatan pemancar stasiun tersebut. Pada sebuah radio, antena hanya menjalankan fungsi penerima saja.

Televisi adalah sebuah media telekomunikasi terkenal yang digunakan untuk memancarkan dan menerima siaran gambar bergerak, baik itu yang monokrom ("hitam putih") maupun warna, biasanya dilengkapi oleh suara. "Televisi" juga dapat diartikan sebagai kotak televisi, rangkaian televisi atau pancaran televisi. Kata "televisi" merupakan gabungan dari kata tele ("jauh") dari bahasa Yunani dan visio ("penglihatan") dari bahasa Latin. Sehingga televisi dapat diartikan sebagai telekomunikasi yang dapat dilihat dari jarak jauh. Penemuan televisi disejajarkan dengan penemuan roda, karena penemuan ini mampu mengubah peradaban dunia. Di Indonesia 'televisi' secara tidak formal disebut dengan TV, tivi, teve atau tipi.(http://google.com).

Ada istilah lain mengenai antena yaitu front-toback-ratio, artinya berapa bagus sebuah antena dapat menerima signal yang datang dari arah antena itu menghadap dibandingkan yang datang dari arah yang berlawanan.

Frekuensi yang digunakan pada televisi adalah pada pita frekuensi VHF (Very Hgh Frequency) dan UHF Ultra High Frequency). VHF dan UHF adalah sebuah bandwidth yang digunakan memancarkan signal radio dan TV pada frekuensi tinggi. Adapun batasan dari kedua band itu adalah : VHF : $30 \mathrm{MHz}-300 \mathrm{MHz}$, saluran 2 - 13 pada TV, UHF: $300 \mathrm{MHz}-3 \mathrm{GHz}$, saluran 14 keatas pada TV. Megahertz artinya "sejuta cycles per detik," jadi "300 megahertz" artinya pemancar stasiun radio tersebut berosilasi pada frekuensi $300,000,000$ cycles per detik.

Antena yang digunakan berbahan dasar alumunium sehingga dapat diperoleh load (beban) yang bisa diterima oleh antenna. Yang bisa dicari dengan rumus $\mathrm{R}=\rho \frac{\lambda}{A}$ Setelah diketahui atau dicari besar dari tahanan atau load antenna maka akan bisa diketahui atau dicari besar daya terima antenna mobil yang digunakan. Antena yang digunakan pada penelitian ini adalah antenna TV dari mobil Ertiga dengan antenna mobil mempunyai luas penampang $3 \mathrm{~mm}^{\wedge} 2$. Dari parameter yang diketahui, $\rho_{A l}=2,65.10^{-8}, \mathrm{~A}=$ $3 \mathrm{~mm}^{2}$ dengan panjang gelombang sesuai data (yang telah disesuaikan dengan perhitungan, maka diperoleh hasil tahanan untuk masing masing televisi. 


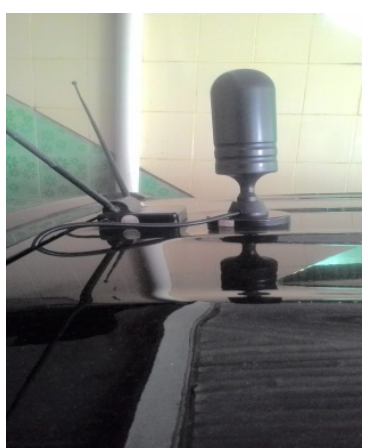

Gambar 2. antenna TV Mobi

Jika ingin memperkuat kemampuannya lagi dalam menerima sinyal frekuensi radio maupun siaran TV, terutama pada kondisi di jalur antar kota, bisa memasang sebuah antena tambahan lagi. Pasalnya versi ini sudah dibekali kemampuan untuk menangkap frekuensi UHF (Ultra High Frequency) maupun VHF (Very High Frequency).

Panjang gelombang minimal dari antenna disini ditentukan cepat rambat gelombang di udara dan frekuensi dari masing-masing televise yang dirumuskan dengan :

$$
\lambda=\frac{c}{f} \ldots \ldots \ldots \ldots \ldots \ldots \ldots \ldots(3.1) \text { dimana }
$$

$\lambda$ : panjang gelombang (meter),

c: cepat rambat gelombang di udara $=3.10^{\wedge} 8 \mathrm{~m} / \mathrm{s}$

$\mathrm{f}$ : frekuensi gelombang.

Adapun hubungan panjang gelombang dan daya terima adalah :

$$
\begin{aligned}
& \mathrm{P}=\frac{V^{2}}{R} \\
& \mathrm{R}=\rho \frac{l}{A}
\end{aligned}
$$

dimana $\mathrm{R}$ : tahanan antenna,

$\rho:$ tahanan jenis antenna $=2,65.10^{-8} \Omega \mathrm{m}$

$l=\lambda$ : panjang gelombang

A : luas penampang antenna. Ambil antenna mobil dengan diameter7 $\mathrm{mm}$ sehingga jari jari $3,5 \mathrm{~mm}$, shg $A \approx$ $3 \mathrm{~mm}^{2}$

Dari hubungan diatas terlihat bahwa panjang gelombang akan berbanding terbalik dengan daya terima antenna.

Dari kedua persamaan diatas pula $(3.1 \& 3.2)$ akan dapat diperoleh panjang gelombang dari masing masing televisi local yang ada. Beberapa

panjang gelombang hasil perhitungan sesuai dengan hasil data yang telah diperoleh :

a. Trans TV, dari tabel diketahui frekuensi 535,31

$\mathrm{MHz}$, cepat rambat gelombang cahaya di udara

$3.10^{8} \mathrm{~m} / \mathrm{s}$, maka dapat diperoleh panjang gelombang dari hasil perhitungan :

$$
\lambda=\frac{c}{f}=\frac{3.10^{8}}{535,31}=560,4 \mathrm{~mm}=
$$

$0,560 \mathrm{~m}$ (seperti pada data)

b. Metro TV, dari tabel diketahui frekuensi 759,31

$\mathrm{MHz}$, cepat rambat gelombang di udara $3.10^{\wedge} 8 \mathrm{~m} / \mathrm{s}$, maka dari hasil perhitungan diperoleh besar panjang gelombang adalah :

$$
\lambda=\frac{c}{f}=\frac{3.10^{8}}{759,31}=395,1 \mathrm{~mm}=
$$

$0.395 \mathrm{~m}$ (seperti pada data)

Frekuensi yang digunakan pada televisi adalah pada pita frekuensi VHF (Very Hgh Frequency) dan
UHF Ultra High Frequency ). VHF dan UHF adalah sebuah bandwidth yang digunakan memancarkan signal radio dan TV pada frekuensi tinggi. Adapun batasan dari kedua band itu adalah : VHF : $30 \mathrm{MHz}$ - $300 \mathrm{MHz}$, saluran 2 - 13 pada TV, UHF: $300 \mathrm{MHz}$ $-3 \mathrm{GHz}$, saluran 14 keatas pada TV. Megahertz artinya "sejuta cycles per detik," jadi "300 megahertz" artinya pemancar stasiun radio tersebut berosilasi pada frekuensi $300,000,000$ cycles per detik.

Antena yang digunakan berbahan dasar alumunium sehingga dapat diperoleh load (beban) yang bisa diterima oleh antenna. Yang bisa dicari dengan rumus (3.3).

\subsection{TELEVISI}

Ada 2 jenis televisi dimana kedua jenis televisi ini juga mempunyai perbedaan prinsip pada penerimaannya yaitu :

\section{Televisi Analog,}

Televisi analog yang akan mengkodekan informasi gambar dengan memvariasikan voltase dan/atau frekuensi dari sinyal. Siaran televisi analog adalah siaran televisi yang dipancarkan dengan menggunakan variasi voltase dan frekuensi dari sinyal. Sistem yang dipergunakan oleh siaran televisi analog adalah NTSC (National Television System Committee), PAL, dan SECAM. Untuk mendapatkan siaran televisi analog digunakan alat penangkap sinyal yang disebut antena. Pada siaran televisi analog, semakin jauh letak antena dari stasiun pemancar televisi, sinyal yang diterima akan melemah dan mengakibatkan gambar yang diterima oleh pesawat televisi menjadi buruk dan berbayang. Di Indonesia, program siaran televisi analog adalah program-program yang dipancarkan oleh stasiun swasta nasional yang disiarkan secara gratis atau free-to-air.

Namun demikian televisi analog mempunyai kekurangan yang cukup penting antara lain, akan memerlukan frekuensi yang sangat tinggi serta kualitas dari audio dan videonya yang kurang tajam serta kurang jernih.

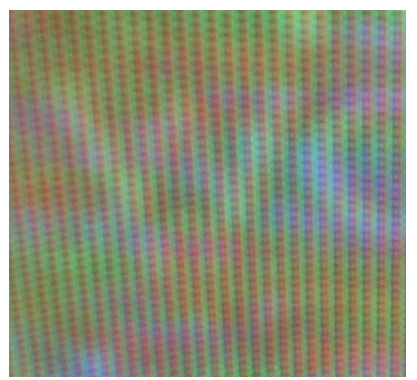

Gambar 3. Siaran televisi analog dilihat dengan pengambilan potret tampak dekat.

\section{Televisi Digital atau DTV}

Televisi Digital atau DTV adalah jenis televisi yang menggunakan modulasi digital dan sistem kompresi untuk menyiarkan sinyal gambar, suara dan data ke pesawat televisi. Televisi digital merupakan alat yang digunakan untuk menangkap siaran TV digital, perkembangan dari sistem siaran 
analog ke digital yang mengubah informasi menjadi sinyal digital berbentuk bit data seperti computer.

TV digital ditunjang oleh teknologi penerima yang mampu beradaptasi sesuai dengan lingkungannya. Sinyal digital dapat ditangkap dari sejumlah pemancar yang membentuk jaringan berfrekuensi sama sehingga daerah cakupan TV digital dapat diperluas. TV digital memiliki peralatan suara dan gambar berformat digital seperti yang digunakan kamera video.

Kelebihan TV digital dengan TV analog adalah memerlukan frekuensi yang relative rendah serta kualitas audio videonya cukup tajam serta jernih.

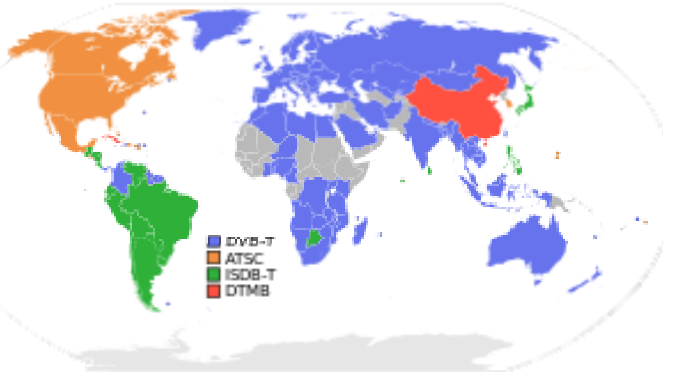

Gambar 4. Peta dunia kemajuan penggunaan televisi digital

\section{Transisi TV analog ke TV Digital}

Transisi dari pesawat televisi analog menjadi pesawat televisi digital membutuhkan penggantian perangkat pemancar televisi dan penerima siaran televisi. Agar dapat menerima penyiaran digital, diperlukan pesawat TV digital. Namun, jika ingin tetap menggunakan pesawat penerima televisi analog, penyiaran digital dapat ditangkap dengan alat tambahan yang disebut rangkaian konverter (Set Top Box).

Sinyal siaran digital diubah oleh rangkaian konverter menjadi sinyal analog, dengan demikian demikian pengguna pesawat penerima televisi analog tetap bisa menikmati siaran televisi digital. Dengan cara ini secara perlahan-lahan akan beralih ke teknologi siaran TV digital tanpa terputus layanan siaran yang digunakan selama ini.

Proses transisi yang berjalan secara perlahan dapat meminimalkan risiko kerugian terutama yang dihadapi oleh operator televisi dan masyarakat. Resiko tersebut antara lain berupa informasi mengenai program siaran dan perangkat tambahan yang harus dipasang tersebut. Sebelum masyarakat mampu mengganti televisi analognya menjadi televisi digital, masyarakat menerima siaran analog dari pemancar televisi yang menyiarkan siaran televisi digital.

Resiko kerugian berasal dari biaya membangun infrastruktur televisi digital terestrial yang relatif jauh lebih mahal dibandingkan dengan membangun infrastruktur televisi analog. Operator televisi dapat memanfaatkan infrastruktur penyiaran yang telah dibangunnya selama ini seperti studio, bangunan, sumber daya manusia dan lain sebagainya.

Penerapan pola kerja dengan calon penyelenggara digital pada akhirnya menyebabkan operator televisi tidak dihadapkan pada risiko yang berlebihan. Di kemudian hari, penyelenggara penyiaran televisi digital dapat dibedakan ke dalam dua posisi yaitu menjadi penyedia jaringan, serta penyedia isi. Pemicu perkembangan TV digital

Yang mendorong perkembangan TV Digital antara lain :

I. Perubahan lingkungan eksternal :

* Pasar televise analog yang sudah jenuh

* Kompetisi dengan system penyiaran satelit dan kabel

II. Perkembangan Teknologi :

* Teknologi pemrosesan sinyal digital

* Teknologi Transmisi digital

* Teknologi semikonduktor

* Teknologi peralatan yang beresolusi tinggi

\subsection{Booster}

Booster adalah alat untuk memperkuat sinyal dari antenna TV ke sebuah atau beberapa buah TV pada bagian outputnya, sehingga kualitas gambar tidak menurun meskipun posisinya bergerak. Booster antenna TV mobil selalu serangkai dengan antenanya. Peletakan bisa secara indoor, bisa juga outdoor. Walaupun peletakan di luar mobil akan membuat booster serta antenna rawan kerusakan, namun penerimaan sinyal dari radio ataupun video akan baik. Antena maupun booster ini biasanya sudah dirangkai di dalam suatu tempat dari bahan isolator yang akan tahan dari panas maupun hujan, sehingga tidak mudah korosi serta bergeser.

Jarak dari antenna maupun booster dari televisi mobil Ertiga yang digunakan disini adalah Standing wave ratio disingkat SWR kadang-kadang disingkat dengan nama VSWR (Voltage Standing Wave Ratio). Bila impedansi saluran transmisi tidak sesuai dengan transceiver maka akan timbul daya refleksi (reflected power) pada saluran yang berinterferensi dengan daya maju (forward power). Interferensi inimenghasilkan gelombang berdiri (standing wave) yang besarnya tergantung pada besarnya daya refleksi. VSWR didefinisikan sebagai perbandingan tegangan maksimum dan tegangan minimum gelombang berdiri pada saluran transmisi.

Penguat ini terdapat pengontrol frekuensi otomatis. Penguat ini terbuat dari transistor yang di produksi oleh pabrik jepang, Penguat di gunakan untuk menerima program televisi dari jarak jauh dengan hasil maksimal. Ketika penerimaan sinyal lemah, penguat meminimalkan bintik-bintik dan warna televisi lebih kontras.

Alat ini berkekuatan (A) $+40-46$ desibel, Untuk mencari tegangan keluaran dari booster ini dapat diambil persamaan penguatan atau gain :

$$
\mathrm{A}=20 . \log \frac{V_{o}}{V_{i}}
$$

Dimana : A : kekuatan alat/ booster (x)

$\mathrm{V}_{\mathrm{o}}$ : tegangan keluaran $(\mathrm{V})$

$V_{i}$ : tegangan masukan ke alat $(\mathrm{V})$

Untuk hasil penggunaan penguat yang maksimal, jalur kabel coaxial 75 ohm yang di pakai sesuai dengan penguat. Penguat atau Booster terbaik sekalipun tidak akan berfungsi dengan baik jika kualiatas kabel yang di pakai tidak bagus. 


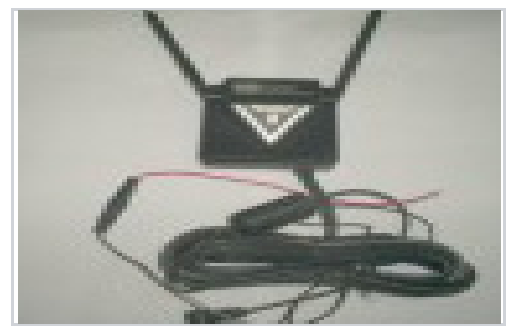

Gambar 4. Booster pada antenna TV mobil

Antena serta booster yang digunakan disini adalah DXX N1508. Dari antenna dan booster yang digunakan dapat diketahui besar bahwa tegangan keluaran antenna dari rumus 3.4. Yaitu :

$A=20 . \log \frac{V_{o}}{V_{i}} \rightarrow$ Jika diambil kekuatan antenna 45 $\mathrm{x}$, tegangan masukan $12 \mathrm{~V}$

Maka : $45=20 . \log \frac{V_{o}}{V_{i}}$

$\log \frac{V_{o}}{V_{i}}=2,25 \rightarrow \frac{V_{o}}{V_{i}}=10^{2,25}=181,9701$

Dengan tegangan masukan serta tahanan yang telah dihitung berdasarkan panjang gelombang serta tahanan masing masing stasiun televisi, maka dapat diperoleh daya terima dari masing-masing stasiun televisi itu berdasarkan persamaan 3.2 yaitu :

$$
\mathrm{P}_{\mathrm{tvri}}=\frac{12^{2}}{131,1 \cdot 10^{-8}}=1,098 \cdot 10^{8} \mathrm{~W}=1098 \cdot 10^{2} \mathrm{MW}
$$

Berdasarkan perhitungan diatas maka akan didapat juga hasil untuk daya terima dari masing masing stasiun televisi. Hasil dari perhitungan yang digabung dengan data yang diperoleh terdapat pada tabel 3.1 :

Tabel 3.1 Data Beberapa parameter Televisi \& Hasil perhitungan

\begin{tabular}{|c|l|l|l|l|}
\hline Nama Televisi & Frekuensi (f) & $\begin{array}{c}\text { Panjang } \\
\text { Gelb. }(\boldsymbol{\lambda})\end{array}$ & \multicolumn{1}{|c|}{ Tahanan ${ }^{\circledR}$} & $\begin{array}{c}\text { Daya Terima } \\
\text { (P) }\end{array}$ \\
\hline TVRI & $: 615,31 \mathrm{MHz}$ & $0,488 \mathrm{~m}$ & $1,311 \mu \Omega$ & $1,098.10^{5} \mathrm{MW}$ \\
\hline TRANS TV & $: 535,31 \mathrm{MHz}$ & $0,560 \mathrm{~m}$ & $4,947 \mu \Omega$ & $29,11 \mathrm{MW}$ \\
\hline MNC TV & $: 599,25 \mathrm{MHz}$ & $0,501 \mathrm{~m}$ & $1,475 \mu \Omega$ & $97,63 \mathrm{MW}$ \\
\hline INDOSIAR & $: 631,3 \mathrm{MHz}$ & $0,475 \mathrm{~m}$ & $4,195 \mu \Omega$ & $34,33 \mathrm{MW}$ \\
\hline ANTV & $: 679,25 \mathrm{MHz}$ & $0,442 \mathrm{~m}$ & $3,904 \mu \Omega$ & $36,89 \mathrm{MW}$ \\
\hline RCTI & $: 647,31 \mathrm{MHz}$ & $0,463 \mathrm{~m}$ & $4,081 \mu \Omega$ & $35,29 \mathrm{MW}$ \\
\hline SCTV & $: 663,31 \mathrm{MHz}$ & $0,453 \mathrm{~m}$ & $4,002 \mu \Omega$ & $35,98 \mathrm{MW}$ \\
\hline GLOBAL TV & $: 711,31 \mathrm{MHz}$ & $0,422 \mathrm{~m}$ & $3,728 \mu \Omega$ & $38,63 \mathrm{MW}$ \\
\hline TV ONE & $: 727,31 \mathrm{MHz}$ & $0,412 \mathrm{~m}$ & $3,639 \mu \Omega$ & $39,57 \mathrm{MW}$ \\
\hline KOMPAS TV & $: 527,31 \mathrm{MHz}$ & $0,569 \mathrm{~m}$ & $5,026 \mu \Omega$ & $28,65 \mathrm{MW}$ \\
\hline METRO TV & $: 759,31 \mathrm{MHz}$ & $0,395 \mathrm{~m}$ & $3,489 \mu \Omega$ & $41,27 \mathrm{MW}$ \\
\hline TRANS 7 & $: 695,25 \mathrm{MHz}$ & $0,431 \mathrm{~m}$ & $3,807 \mu \Omega$ & $37,83 \mathrm{MW}$ \\
\hline
\end{tabular}

\subsection{Hasil Penelitian Lapangan}

Ada beberapa parameter yang perlu diperhitungkan pada penerimaan siaran video di dalam mobil Ertiga, baik pada penangkapan siaran televisi maupun VCD/ DVD. Pada siaran TV lokal maupun nasional perlu diketahui frekuensi masingmasing TV yang dimaksud. Pembagian frekuensi dari TV swasta maupun TVRI antara lain :
Frekuensi dari masing-masing Televisi telah diketahui, semuanya mempunyai harga dalam batas kawasan Ultra High Frekuency $(300 \mathrm{Mhz}-3 \mathrm{GHz}$. Dari beberapa parameter serta rumus yang diketahui maka akan dapat dihitung daya terima antenna televisi mobil seperti yang telah tercantum dalam tabel 3.1 diatas.

Setelah melakukan perjalanan dengan medan yang cukup bervariasi sambil menyaksikan siaran televisi local dari dalam mobil, maka dapat dilakukan perhitungan serta penyesuain dari harga atau nilai yang seharusnya sehingga akan didapat tampilan atau siaran televisi local secara maksimal atau baik, jauh dari gangguan (noise). Dari tabel nama televisi serta frekuensi dan panjang gelombangnya akan dapat dilakukan atau diprediksi tentang kualitas siarannya.

Gambar atau hasil siaran local dari televisi mobil dengan menggunakan 2 antena, antenna analog dan antenna digital untuk masing-masing televisi :

a. TVRI
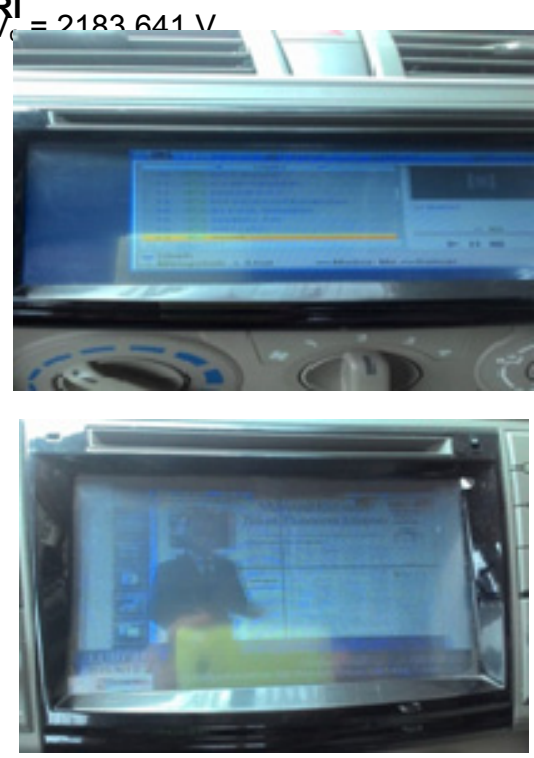

b. MNC TV
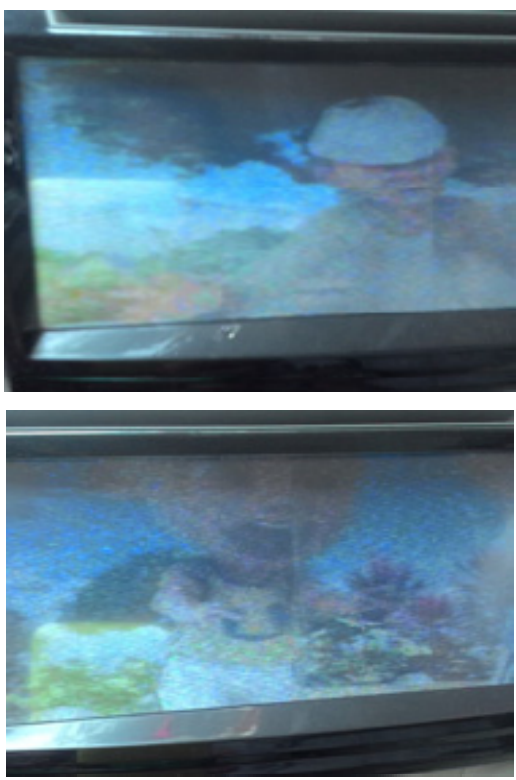


\section{TRANS 7}
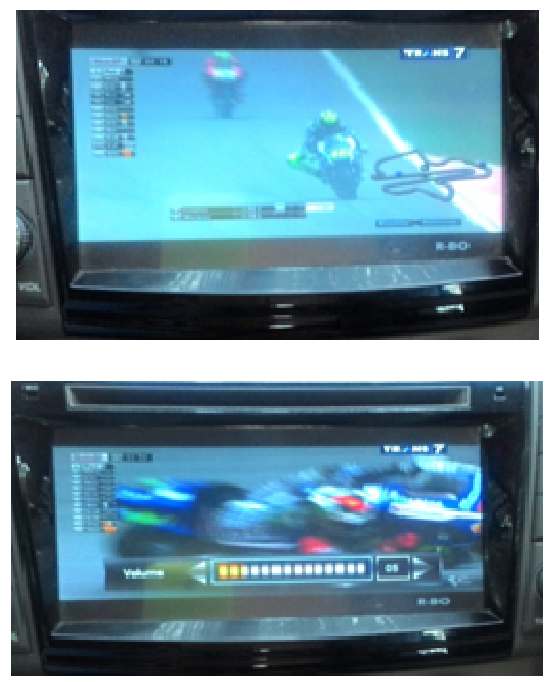

\section{d. SCTV}
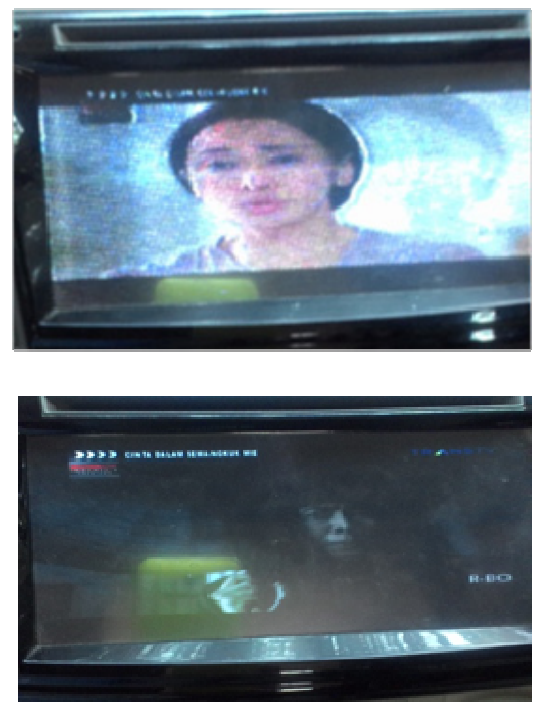

e. Metro TV
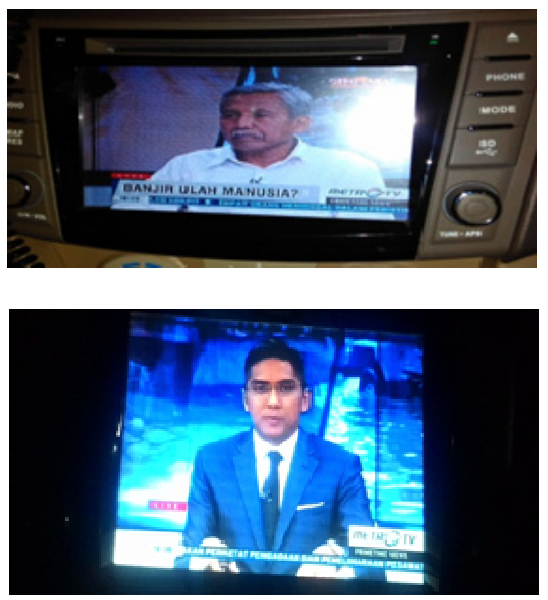

\section{KESIMPULAN}

\subsection{Kesimpulan}

Dari penelitian yang dilakukan dapat disimpulkan :

1. Penerimaan siaran televisi mobil akan jernih, bersih jika komponen yang digunakan cocok atau sesuai dengan petunjuk dari buku petunjuknya.

2. Panjang gelombang yang terhitung adalah yang terpendek tetapi dengan frekuensi terbesar yaitu siaran dari televisi metro dengan frekuensi $759,31 \mathrm{MHz}$, panjang gelombang 0,395 meter dan daya terima antenna untuk televisi ini 41,27 MW tahanan 3,489 $\mu \Omega$ memberikan tampilan siaran atau broadcast televisi yang paling baik. Disini besar daya terima adalah terbesar diantara televisi yang diteliti, tahanannya terkecil diantara televisi yang diteliti.

3. Selain yang tersebut pada kesimpulan nomor 2, baiknya siaran pada TV Metro sudah cukup lama menggunakan siaran digital yang tentunya sudah mempunyai kestabilan siaran secara digital yang cukup stabil.

3. Dari penelitian ini besar penguatan sesuai buku petunjuk adalah $40-46 \mathrm{~dB}$. Jika diambil penguatan 45 , makabesar tegangan keluaran dari antenna adalah 2183,641 Volt.

\section{DAFTAR PUSTAKA}

[1] Kartika Roni, 2016, Antena Alumunium Guna Optimasi Gelombang Radio, Jurnal Kilat STTPLN Jakarta

[2] Kartika Roni, Ari Endang, M Sipan, 2014, Perbandingan bahan Dasar Antena, Jurnal Rekayasa dan Pengembangan Teknologi LPPM USM Semarang.

[3] Eko Riyanto SUTOMO, 2012, Menyongsong Penggunaan Penyiaran TV Digital di Indonesia, Buletin Informasi SDPPI Edisi ketiga.

[4] Bidyut K. Sen, 2008, Skin Effects models for Transmission Line Structures using Generic SPICE Circuit Simulators, Sun Microsystems Inc. 901 San Antonio Road, MS USUN02-301 Palo Alto, CA 94303

[5] Cyclades (Syros), 2008, FirstBroadcasts 60 UHF.

[6] Eko Riyanto SUTOMO, 2012, Menyongsong Penggunaan Penyiaran TV Digital di Indonesia, Buletin Informasi SDPPI Edisi ketiga.

[7] Greece, 2015, Transition To Digital TV

[8] Indovision DIY, 2016, TV Digital Massa Depan, Cipta Massa Selaras.

[9] John R. Quain, 2015, Best Indoor's Antennas, U.S Edition

[10] Tjahyono Bambang Heru, 2006, Sistem Jaringan Penyiaran Radio \& TV Dimasa Mendatang.

[11] www. Google.search. DTT around the world and digital television transition. Unduh 10 Agustus 2015 